\title{
Glass-Ceramic Foams from 'Weak Alkali Activation' and Gel-Casting of Waste Glass/Fly Ash Mixtures
}

\author{
Acacio Rincón Romero ${ }^{1}\left(\mathbb{D}\right.$, Nicoletta Toniolo $^{2}$, Aldo R. Boccaccini ${ }^{2}\left(\mathbb{1}\right.$ and Enrico Bernardo ${ }^{1, *}$ (i) \\ 1 Department of Industrial Engineering, University of Padova, Via Marzolo 9, \\ Padova 35131, Italy; acacio.rinconromero@unipd.it \\ 2 Institute of Biomaterials, Department of Materials Science and Engineering, \\ University of Erlangen-Nuremberg, Cauerstraße 6, 91058 Erlangen, Germany; \\ nicoletta.t.toniolo@fau.de (N.T.); aldo.boccaccini@ww.uni-erlangen.de (A.R.B.) \\ * Correspondence: enrico.bernardo@unipd.it; Tel.: +39-049-827-5510; Fax: +39-049-827-5505
}

Received: 10 December 2018; Accepted: 12 February 2019; Published: 15 February 2019

check for updates

\begin{abstract}
A 'weak alkali activation' was applied to aqueous suspensions based on soda lime glass and coal fly ash. Unlike in actual geopolymers, an extensive formation of zeolite-like gels was not expected, due to the low molarity of the alkali activator $(\mathrm{NaOH})$ used. In any case, the suspension underwent gelation and presented a marked pseudoplastic behavior. A significant foaming could be achieved by air incorporation, in turn resulting from intensive mechanical stirring (with the help of a surfactant), before complete hardening. Dried foams were later subjected to heat treatment at $700-900{ }^{\circ} \mathrm{C}$. The interactions between glass and fly ash, upon firing, determined the formation of new crystal phases, particularly nepheline (sodium alumino-silicate), with remarkable crushing strength ( $\sim 6 \mathrm{MPa}$, with a porosity of about $70 \%)$. The fired materials, finally, demonstrated a successful stabilization of pollutants from fly ash and a low thermal conductivity that could be exploited for building applications.
\end{abstract}

Keywords: alkali activation; inorganic gel casting; glass-ceramic foams; waste glass; fly ash

\section{Introduction}

Coal fly ash is a fundamental waste produced by power stations; it consists of a fine particulate material with fluctuating chemical and phase compositions, depending on the original coal and burning conditions, configuring a significant environmental issue. In fact, despite the exploitation of renewable energy resources, the amounts of waste generated worldwide are increasing (the currently produced amount, of about 900 million tons, is expected to increase up to 2 billion tons in 2020) [1]. Coal fly ash is mainly landfilled, producing significant dangers, such as the potential leaching of heavy metals or polycyclic aromatic hydrocarbons [2-4]. As a consequence, the use of coal fly ash in new valuable materials is a critical issue for a sustainable society.

Significant amounts of fly ash are used in the building industry, due to their pozzolanic properties: mixed with cement, they are well known to improve concrete durability $[3,5,6]$. Fly ash valorization has also been realized by the production of dense glass-ceramic materials, to be used as an alternative to natural stones or traditional ceramic tiles $[7,8]$.

Compared to dense glass-ceramics, lightweight glass-ceramic foams, to be used for thermal and acoustic insulation, may represent a more valuable product. Waste glass/fly ash mixtures have been variously foamed, by viscous flow sintering of glass, determining a pyroplastic mass (in turn incorporating fly ash), with concurrent gas evolution, by the addition of different foaming agents, such as $\mathrm{SiC}$ [9]. The amount and nature of waste glass are significant in reducing the processing temperature $[10,11]$. As an example, carbonates, in the form of dolomite $\left(\mathrm{CaMg}\left(\mathrm{CO}_{3}\right)_{2}\right)$, or sludge from 
a marble cutting-polishing plant (containing mainly calcite, $\mathrm{CaCO}_{3}$ ) may lead to ceramic foams with low apparent density $\left(0.36-0.41 \mathrm{~g} / \mathrm{cm}^{3}\right)$ and relatively high compressive strength values $(2.4-2.8 \mathrm{MPa})$. However, the highest amount that could be incorporated for the foam production does not exceed $20 \mathrm{wt} \%$ [3]. Coal fly ash may be increased up to $40 \mathrm{wt} \%$, in foams generated by means $\mathrm{CaCO}_{3}$ decomposition, but $30 \mathrm{wt} \%$ borax must be considered as extra fluxing agent [11]. Some attempts to produce lightweight aggregates have been made even avoiding the use of any foaming agents, e.g., by mixing the fly ash $(75 \mathrm{wt} \%)$ and waste window panes $(25 \mathrm{wt} \%)$ exploiting the bloating of the fly ash at high temperature [12].

According to the fact that fly ash is rich in amorphous alumina and silica, another promising application concerns the formulation of waste-derived geopolymers [13]. Geopolymer materials are a class of inorganic polymers synthesized through the reaction of a solid alumino-silicate precursor with a highly concentrated alkali solution. When immersed in strongly alkaline solutions, the alumino-silicate-reactive materials are almost entirely dissolved, leading to the formation of hydrated alumino-silicate oligomers, including $\left[\mathrm{SiO}_{4}\right]$ and $\left[\mathrm{AlO}_{4}\right]$ tetrahedral units. The following polymerization of the oligomers creates a highly stable three-dimensional network structure where the $\left[\mathrm{SiO}_{4}\right]$ and $\left[\mathrm{AlO}_{4}\right]$ tetrahedra are linked together by sharing oxygen atoms. This structure ('zeolite-like

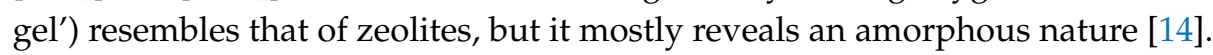

The use of fly ash in the geopolymer formulation, alone or mixed with other natural sources or industrial wastes, has been widely studied [15-17], with the perspective of obtaining inorganic binders with low $\mathrm{CO}_{2}$ emissions (compared to ordinary Portland cement) and reduced use of natural raw materials [18,19]. These advantages, however, are somewhat counterbalanced by the costs of the standard reagents used as alkali activators in fly ash geopolymer-based materials, such as sodium silicate (also known as water glass) and sodium or potassium hydroxide [20,21]. In fact, it should be noted that significant energy demand and $\mathrm{CO}_{2}$ emissions are associated with sodium silicate production, where temperatures around $1300{ }^{\circ} \mathrm{C}$ are required, in order to melt sodium carbonate and silica mixtures [22]. Some efforts have recently been made to substitute the conventional activators with low cost and more environmentally friendly alternatives, such as industrial residues of discarded cleaning solutions for aluminum molds [23] and, above all, waste glass [24].

In recent investigations, we proposed the synthesis of dense fly ash [25] or red mud [26] based geopolymers using waste glass from municipal waste collection, replacing water glass as main silica source in the geopolymeric formulation. It was established that, despite the alternative formulation, stable and chemically resistant geopolymeric gels could be obtained by mixing fly ash and waste glass, in an appropriate ratio, and using $\mathrm{NaOH}$ in relatively low molarities ( $\mathrm{NaOH} 8 \mathrm{M})$ [25]. The present investigation was conceived as a further extension of the approach, in the development of inorganic gels with an even weaker alkali activation of waste glass/fly ash aqueous suspensions. The suspensions were subjected to extensive foaming (by mechanical stirring) at the early stage of gelation, leading to highly porous bodies later stabilized by means of a low temperature firing treatment.

\section{Materials and Methods}

The initial raw materials used in this study were low calcium fly ash (FA) class F (ASTM C 618) [27], with a mean particle size of $20 \mu \mathrm{m}$, supplied by Steag Power Minerals (Dinslaken, Germany), and soda-lime glass waste (SLG), produced by SASIL S.r.l. (Brusnengo, Biella, Italy) as fine powders with a particle size under $30 \mu \mathrm{m}$. In particular, we considered the finest fraction produced during the purification process of glass cullet carried out in the company, with limited industrial application. Table 1 summarizes the chemical composition of the two basic raw materials determined by means of X-ray fluorescence [25].

FA/SLG were prepared by progressive addition of powders into an $\mathrm{NaOH}$ aqueous solution, for a liquid/solid of 0.45 . According to a methodology already presented in previous studies $[25,26]$, we varied the theoretical molar ratio between $\mathrm{SiO}_{2}$ and $\mathrm{Al}_{2} \mathrm{O}_{3}$ in the final product by changing the FA and SLG proportions, being 76/24,64/36, 54/46, corresponding to a $\mathrm{SiO}_{2} / \mathrm{Al}_{2} \mathrm{O}_{3}$ theoretical molar 
ratio of 5, 6, and 7, respectively. However, in this case, a lower concentration (3M) of $\mathrm{NaOH}$ was considered. As in previous studies, the mixtures were kept under low-speed mechanical stirring (500 rpm) for $4 \mathrm{~h}$, to ensure a good dissolution of the starting materials and the proper dispersion of the remaining undissolved particles in the slurries.

Table 1. Chemical composition (expressed in $\mathrm{wt} \%$ ) of the starting materials.

\begin{tabular}{ccccccccc}
\hline Oxide (wt $\%)$ & $\mathbf{S i O}_{\mathbf{2}}$ & $\mathbf{A l}_{\mathbf{2}} \mathbf{O}_{\mathbf{3}}$ & $\mathbf{N a}_{\mathbf{2}} \mathbf{O}$ & $\mathbf{K}_{\mathbf{2}} \mathbf{O}$ & $\mathbf{C a O}$ & $\mathbf{M g O}$ & $\mathbf{F e}_{\mathbf{2}} \mathbf{O}_{\mathbf{3}}$ & $\mathrm{TiO}_{\mathbf{2}}$ \\
\hline FA & 54.36 & 24.84 & 0.83 & 3.03 & 2.56 & 2.06 & 8.28 & 1.07 \\
SLG & 70.5 & 3.2 & 12 & 1 & 10 & 2.3 & 0.42 & 0.07 \\
\hline
\end{tabular}

The suspensions were foamed by the addition of $4 \mathrm{wt} \%$ of an aqueous solution of sodium lauryl sulphate (SLS) $\left(\mathrm{CH}_{3}\left(\mathrm{CH}_{2}\right)_{11} \mathrm{OSO}_{3} \mathrm{Na}\right.$, supplied by Carlo Erba, Cornaredo, Milan, Italy), previously prepared with a SLS/water $=1 / 10$ and then by application of vigorous mechanical stirring (2000 rpm) for $10 \mathrm{~min}$. The prepared wet foams were poured into cylindrical molds $(6 \mathrm{~cm}$ diameter $)$ and kept at $60{ }^{\circ} \mathrm{C}$ for $48 \mathrm{~h}$ in sealed conditions. Dried samples were finally demolded and subjected to thermal treatment at 800,900 , and $1000^{\circ} \mathrm{C}$ for $1 \mathrm{~h}\left(10{ }^{\circ} \mathrm{C} / \mathrm{min}\right.$ heating rate). The overall manufacturing process is represented by Figure 1.

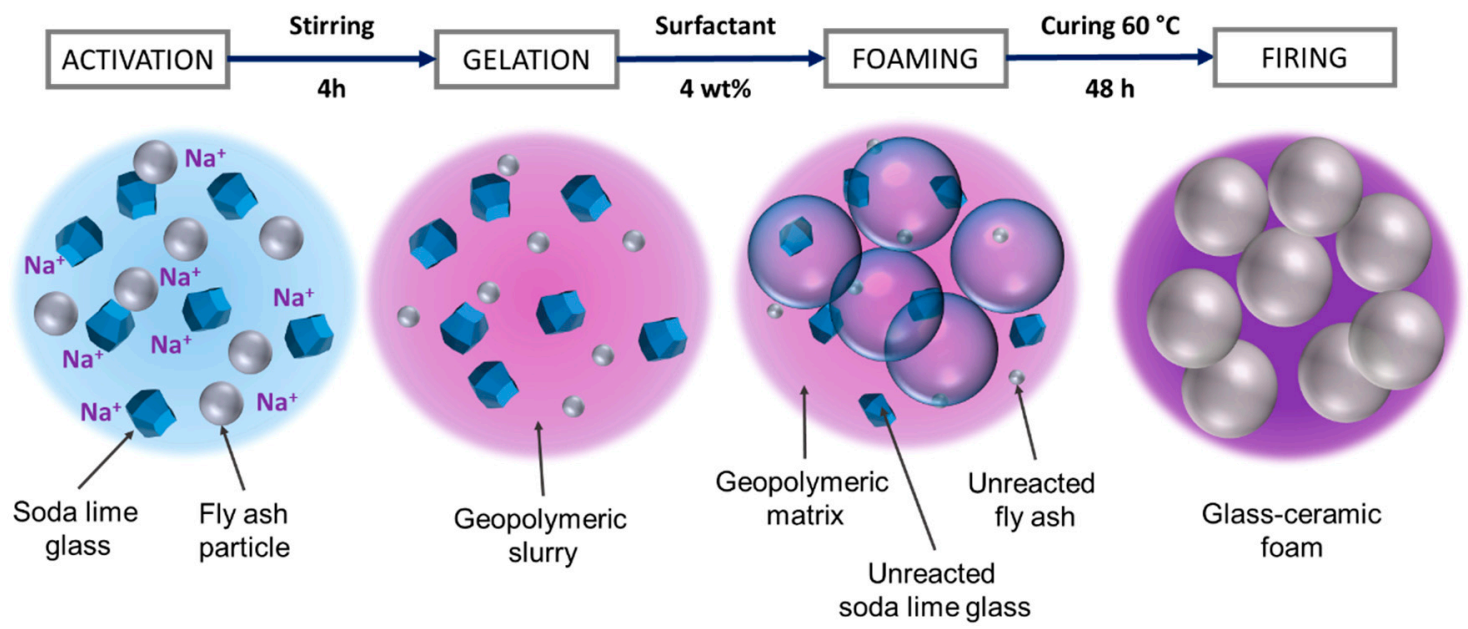

Figure 1. Processing scheme for the production of glass-ceramic foams.

X-ray diffraction analyses (XRD) were carried out on powdered samples (Bruker D8 Advance, Karlsruhe, Germany) using $\mathrm{CuK} \alpha$ radiation $(0.15418 \mathrm{~mm}), 40 \mathrm{kV}-40 \mathrm{~mA}$, and $2 \theta$ angles between $10-70^{\circ}$. A step size of $0.02^{\circ}$ and $2 \mathrm{~s}$ counting time was set for the analysis of the starting materials and of the hardened foams. A step size of $0.02^{\circ}$ and a $0.5 \mathrm{~s}$ counting time was adopted for the fired samples. The phase identification was performed using the Match! ${ }^{\circledR}$ software suite (Crystal Impact GbR, Bonn, Germany), supported by data from PDF-2 database (ICDD- International Centre for Diffraction Data, Newtown Square, PA, USA).

Samples form larger specimens were cut to about $10 \times 10 \times 10 \mathrm{~mm}$. The bulk density was evaluated considering the mass measured with an analytical balance and the volume carefully measured with a digital caliper. The apparent and true densities were determined using a helium pycnometer (Micromeritics AccuPyc 1330, Norcross, GA, USA), working on foamed samples or on fine powders from crushed samples, respectively. The total, open, and closed porosity were computed using the three density values. Compression tests were done using an Instron 1121 UTS (Instron, Danvers, MA, USA) machine, with a crosshead speed of $0.5 \mathrm{~mm} / \mathrm{min}$, with each data point corresponding to 9-10 samples.

The European Standard for the compliance test for leaching of granular waste materials and sludge (EN 12457-2) was followed to evaluate the release of heavy metals in the initial raw materials 
and in selected fired samples. Fragments below $4 \mathrm{~mm}$ were placed in distilled water with a $\mathrm{pH}$ value of $\sim 7$ to a liquid/solid ratio of 10 , softly stirred at $25^{\circ} \mathrm{C}$ for $24 \mathrm{~h}$. The resulting eluates were filtered through a $0.6 \mu \mathrm{m}$ filter and analyzed using inductively coupled plasma (ICP; SPECTRO Analytical Instruments $\mathrm{GmbH}$, Kleve, Germany).

The semi-industrial production of lightweight panels was developed for selected samples. The alkali activation process was conducted in the same way. However, a relatively significant amount of activated suspension was prepared for each batch (around $5 \mathrm{~kg}$ ), and the process was carried out with technical grade reagents. The hardened foamed panels were obtained after casting the wet foams in bigger molds $(15 \mathrm{~cm} \times 20 \mathrm{~cm})$. Finally, hardened foamed gels were fired at $800{ }^{\circ} \mathrm{C} \mathrm{for} 1 \mathrm{~h}$, using a pilot scale tunnel furnace (Nanetti ER-15S) at SASIL S. p. a. (Brusnengo, Biella, Italy).

Thermal conductivity tests on the lightweight panels were performed using a Fox 50 Heat Flow Meter by TA Instruments (New Castle, DE, USA) operating at $25^{\circ} \mathrm{C}$. The measure was conducted on cylindrical samples (50 mm diameter and $10 \mathrm{~mm}$ thickness) cut from the panels; three replicated tests were performed on samples taken from different panels.

\section{Results and Discussion}

Figure 2 shows the microstructure for the geopolymer foam after $24 \mathrm{~h}$ of curing for the mixtures 5S, 6S, and 7S (Figure 2a-c, respectively). The hardened foams reveal a high microstructural uniformity, presenting pores in a range from 10 to $30 \mu \mathrm{m}$ diameter. No significant changes in the pore distribution between samples with different compositions can be detected, even if the viscosity of the initial slurries was different. High amounts of glass were expected to determine a slight viscosity increase [28], but the spherical morphology of the FA ensured good workability in all conditions; the observed great homogeneity presented can be explained thanks to the rapid setting of the wet foams, preventing any coalescence effect [29].
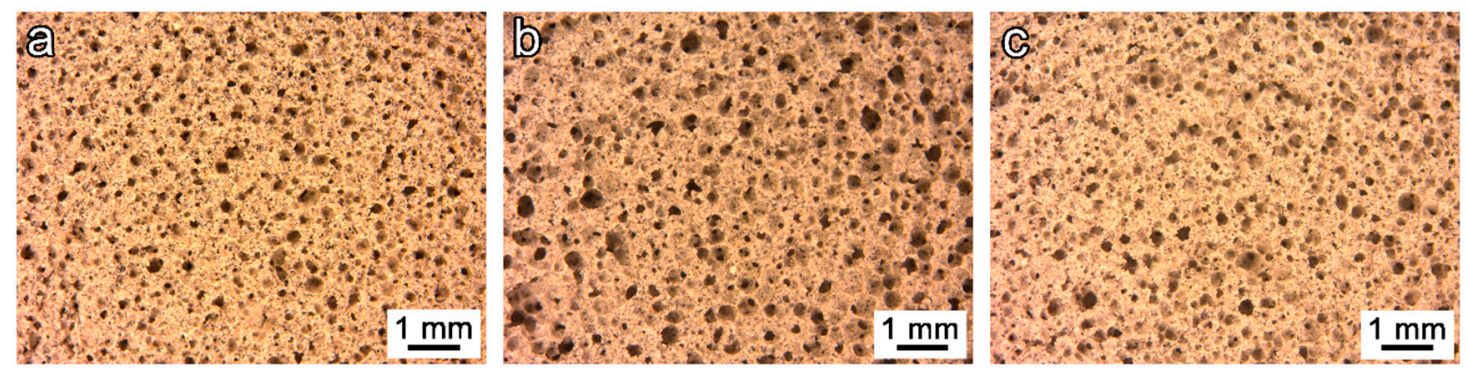

Figure 2. Microstructural details of the soda-lime glass waste/fly ash (SLG/FA foams in the hardened state; (a) 5S; (b) 6S, and (c) 7S.

The X-ray diffraction patterns of the starting materials are illustrated in Figure 3; a different intensity scale was selected for each material in order to highlight the crystalline phases present (the intensity of the strongest peak in Figure $3 b$ is $~ 20$ times higher than the intensity of the strongest peak in Figure 3a). SLG (Figure 3a) presents the typical 'amorphous halo' of silicate glasses centered approximately at $2 \theta=24-26^{\circ}$, along with weak peaks, attributed to hydrated phases, such as calcium aluminum silica hydrate (gismondine $\mathrm{CaAl}_{2} \mathrm{Si}_{2} \mathrm{O}_{8} \cdot 4 \mathrm{H}_{2} \mathrm{O}$, PDF\#020-0452), calcium silica hydrate $\left(\mathrm{Ca}_{1.5} \mathrm{SiO}_{3.5} \cdot \mathrm{xH}_{2} \mathrm{O}\right.$, PDF\#033-0306), and sodium aluminum silica hydrate $\left(\mathrm{K}_{2} \mathrm{NaAl}_{3} \mathrm{Si}_{9} \mathrm{O}_{4} \cdot 7 \mathrm{H}_{2} \mathrm{O}\right.$, PDF\#022-0773). These hydrated phases had formed probably according to surface reaction of fine glass particles with environmental humidity during storage.

The original fly ash (Figure 3b) contained quartz $\left(\mathrm{SiO}_{2}, \mathrm{PDF} \# 083-0539\right)$ and mullite $\left(\mathrm{Al}_{4} \mathrm{SiO}_{8}\right.$, PDF\#079-1275) as the main crystal phases; moreover, minor traces of hematite $\left(\mathrm{Fe}_{2} \mathrm{O}_{3}, \mathrm{PDF} \# 033-0664\right)$ were also detected. In the pattern, it is still possible to detect an amorphous halo at around $24-26^{\circ}$. 

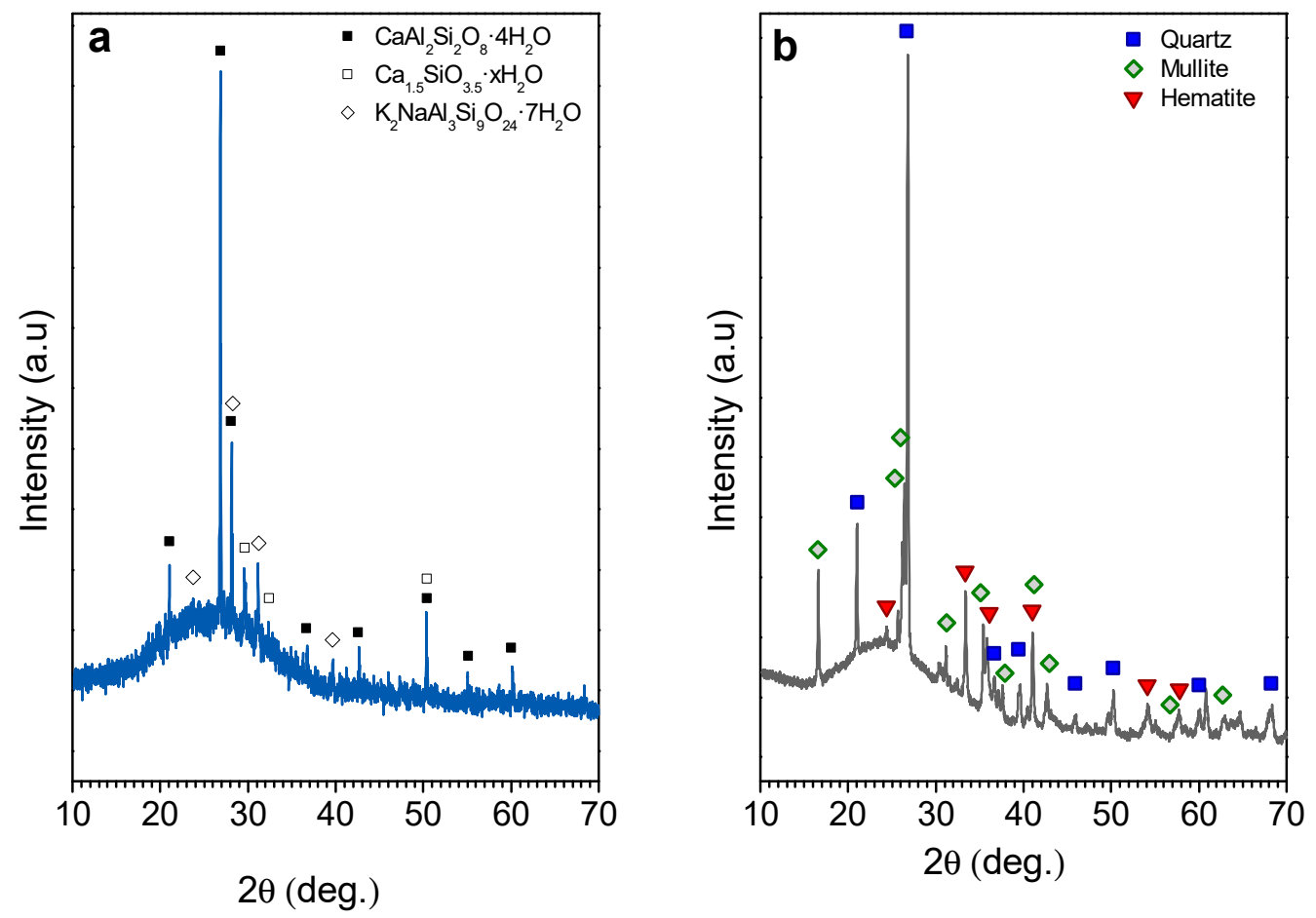

Figure 3. X-ray diffraction patterns of the initial materials (a) waste soda lime glass and (b) fly ash.

The X-ray diffraction patterns of the hardened foams represented in Figure 4 show that quartz and mullite from the initial fly ash remained practically unaltered. The intensity of these peaks simply decreased with a higher amount of glass in the initial formulation; as a result of this 'dilution' effect, hematite $\left(\mathrm{Fe}_{2} \mathrm{O}_{3}, \mathrm{PDF} \# 033-0664\right)$ is no longer visible.

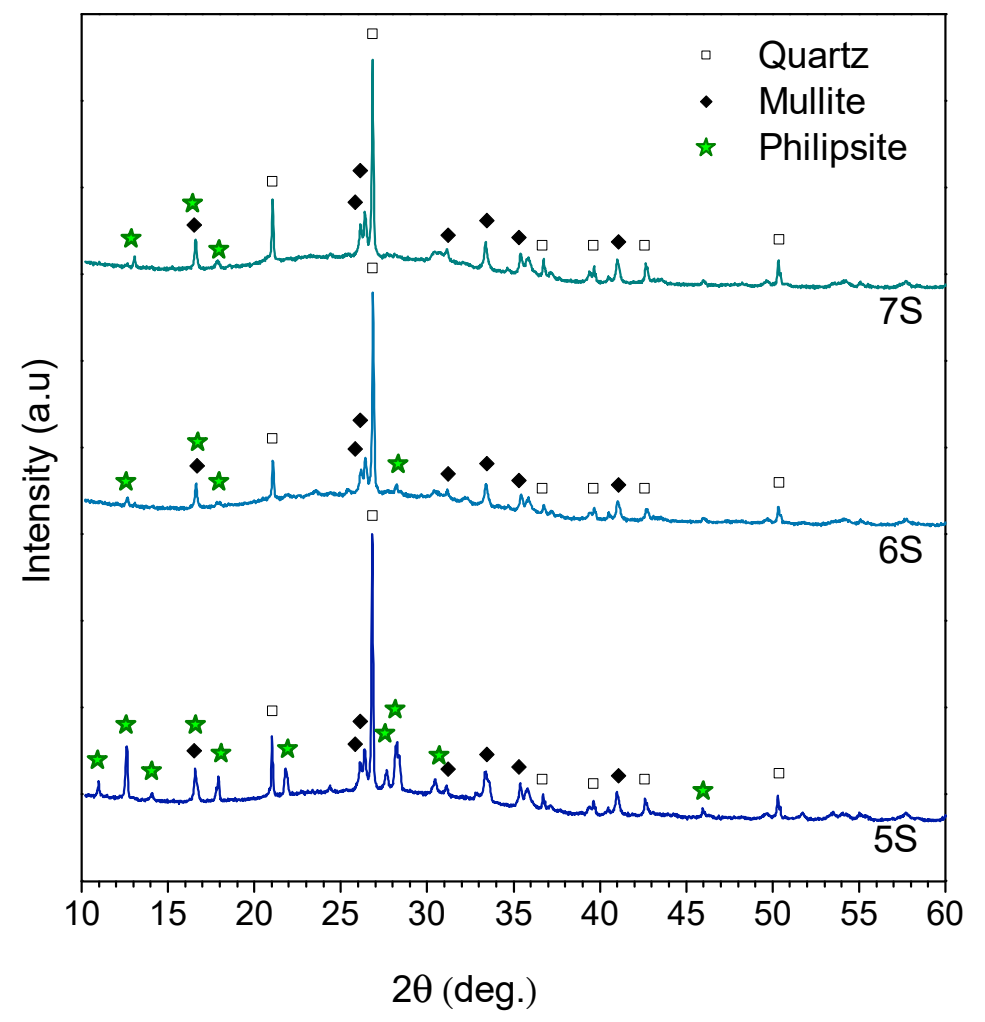

Figure 4. X-rays diffraction patterns of the hardened geopolymeric foams. 
The center of the amorphous halo moved from $2 \theta \sim 24^{\circ}$, in the original raw materials, to $2 \theta \sim 30^{\circ}$, after alkali activation. This shift is consistent with the literature on geopolymers, concerning the development of an alkaline alumino-silicate hydrate ( $\mathrm{N}-\mathrm{A}-\mathrm{S}-\mathrm{H})$ gel as a reaction product [30-32].

A second change, with alkali activation, concerns the presence of philipsite $\left(\mathrm{Na}_{4} \mathrm{KAl}_{5} \mathrm{Si}_{11} \mathrm{O}_{32}\left(\mathrm{H}_{2} \mathrm{O}\right)_{10}\right.$, PDF\#073-1419), as newly formed crystal phase, for all compositions. This phase, a sodium potassium aluminum silicate hydrate with a zeolite-type structure, has already been detected in geopolymeric gels $[33,34]$. Although quite rough, both shift of amorphous halo and formation of philipsite could be considered as a proof of the reaction between starting materials and development of a semi-crystalline 'geopolymer-like' gel.

Microstructural details of the cell struts from hardened sample 5S were studied using SEM (Figure 5). The low magnification image (Figure 5a) reveals the spherical shape of the fly ash mixed with irregular shape particles of SLG. As could be noticed, the low activator molarity did not allow a significant dissolution of the initial raw materials. However, the reaction products detected in the X-ray analysis effectively promoted the binding of adjacent particles in the hardened samples. At higher magnification, zeolite crystals were well visible on the surface of the unreacted particles (Figure 5b). The particular morphology of deposits on spherical fly ash particles is typically associated with the formation of zeolite compounds $[35,36]$.

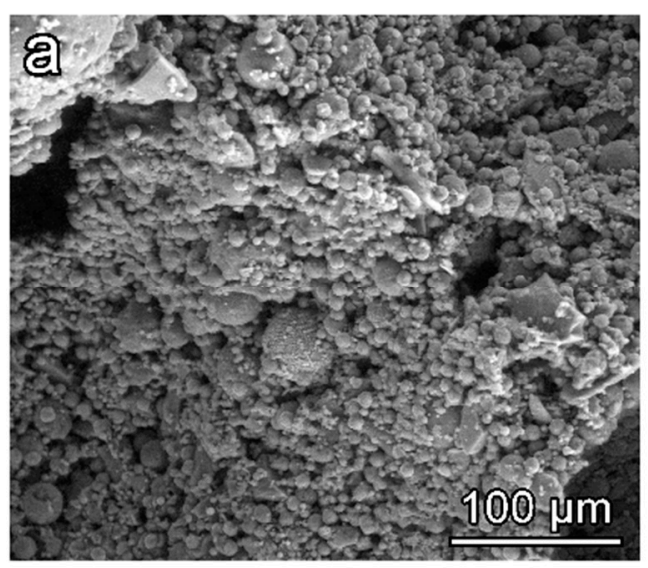

Figure 5. High magnification morphology of 5S hardened state foam: (a) Low magnification; (b) high magnification.

The hardened foams kept their structural integrity after drying. However, after immersion in boiling water, the water became turbid, and $\mathrm{pH}$ rapidly approached 13 . This fact revealed the poor chemical stability of the hardened samples when activated at low molarity and justified the application of a firing treatment for further stabilization.

The weight losses of the initial SLG waste and FA are presented in Figure 6a. The waste glass presents a negligible loss of weight around $1 \mathrm{wt} \%$ at $700{ }^{\circ} \mathrm{C}$, which is attributed to the burn-out of the plastic impurities inside the waste glass fraction. The weight losses of the FA are approximately $4 \mathrm{wt} \%$ in the temperature range studied $\left(20-1200{ }^{\circ} \mathrm{C}\right)$. Losses between 200 and $800{ }^{\circ} \mathrm{C}$ are associated with the combustion of carbon present in the FA, and marginal loss of near $1 \mathrm{wt} \%$ at $1000{ }^{\circ} \mathrm{C}$ is associated with sulphate decomposition [37].

The TGA results of the hardened samples shown in Figure $6 \mathrm{~b}$ reveal a higher weight loss with the higher content of fly ash in the initial formulation. The surfactant influence is not taken into account as it is added in an aqueous solution $1 / 10$, so the total weight loss attributed to it could not exceed $0.4 \%$.

It is quite challenging to identify the weight losses in the hardened foams, as they are the result of decomposition reaction of several compounds. Two principal changes, however, could be reasonably explained. The gradual weight loss up to $500{ }^{\circ} \mathrm{C}$ was attributed mainly to the evaporation of physical bonded and combined water in the gel, whereas the loss at $500-700{ }^{\circ} \mathrm{C}$ is thought to correspond 
mainly to the carbon combustion and secondly to the final dehydration of the C-S-H and N-A-S-H compounds [38]. Beyond $700{ }^{\circ} \mathrm{C}$, the weight losses were stabilized in all the samples, and only the sulphate decomposition from the initial fly ash could be noticed [37].

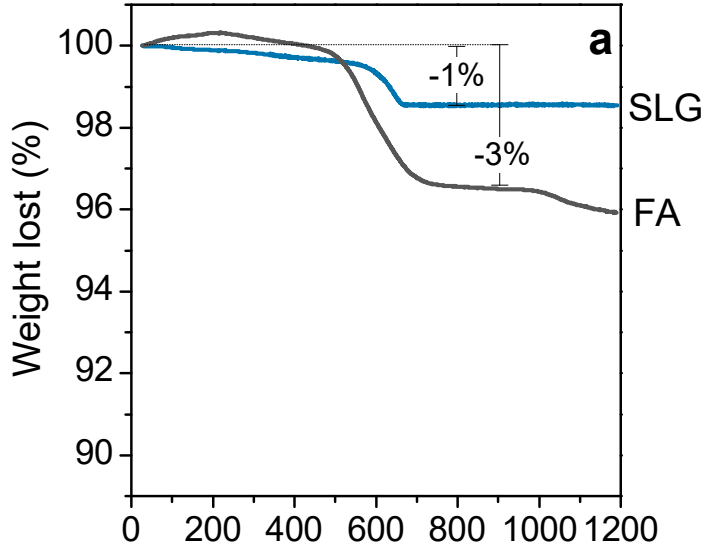

Temperature $\left({ }^{\circ} \mathrm{C}\right)$

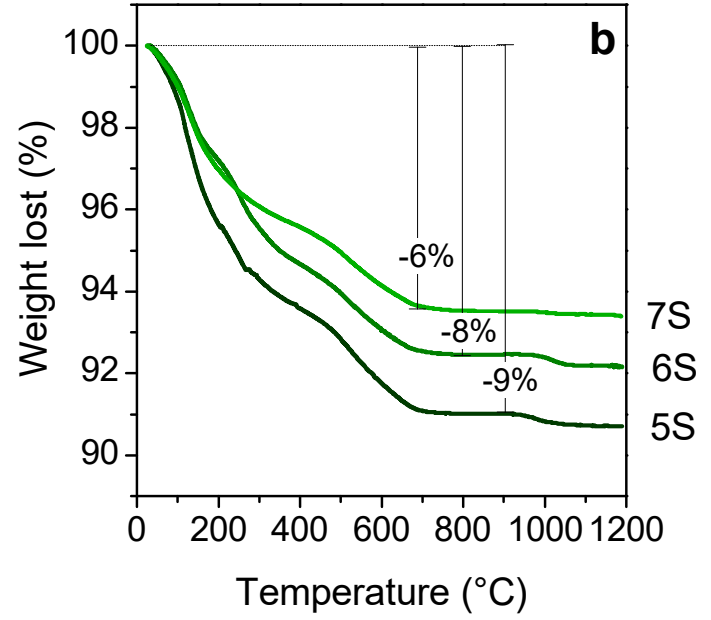

Temperature $\left({ }^{\circ} \mathrm{C}\right)$

Figure 6. Differential thermal analysis plots; (a) initial soda lime glass cullet and fly ash; (b) hardened foams.

After the heat treatment, all the samples resulted in well-sintered bodies, illustrated in Figure 7. Homogeneous well distributed round pores, with diameters from 10-30 $\mu \mathrm{m}$, remained from the initial structure (after hardening). Even if the treatment temperature between $700-900{ }^{\circ} \mathrm{C}$ was well beyond the softening point of glass (around $650{ }^{\circ} \mathrm{C}$ ), no coalescence of the cells, by viscous flow, could be observed, as an effect of the presence of crystal inclusions evolved from FA as well as from glass/FA interactions, and that increased the apparent viscosity on the melt.
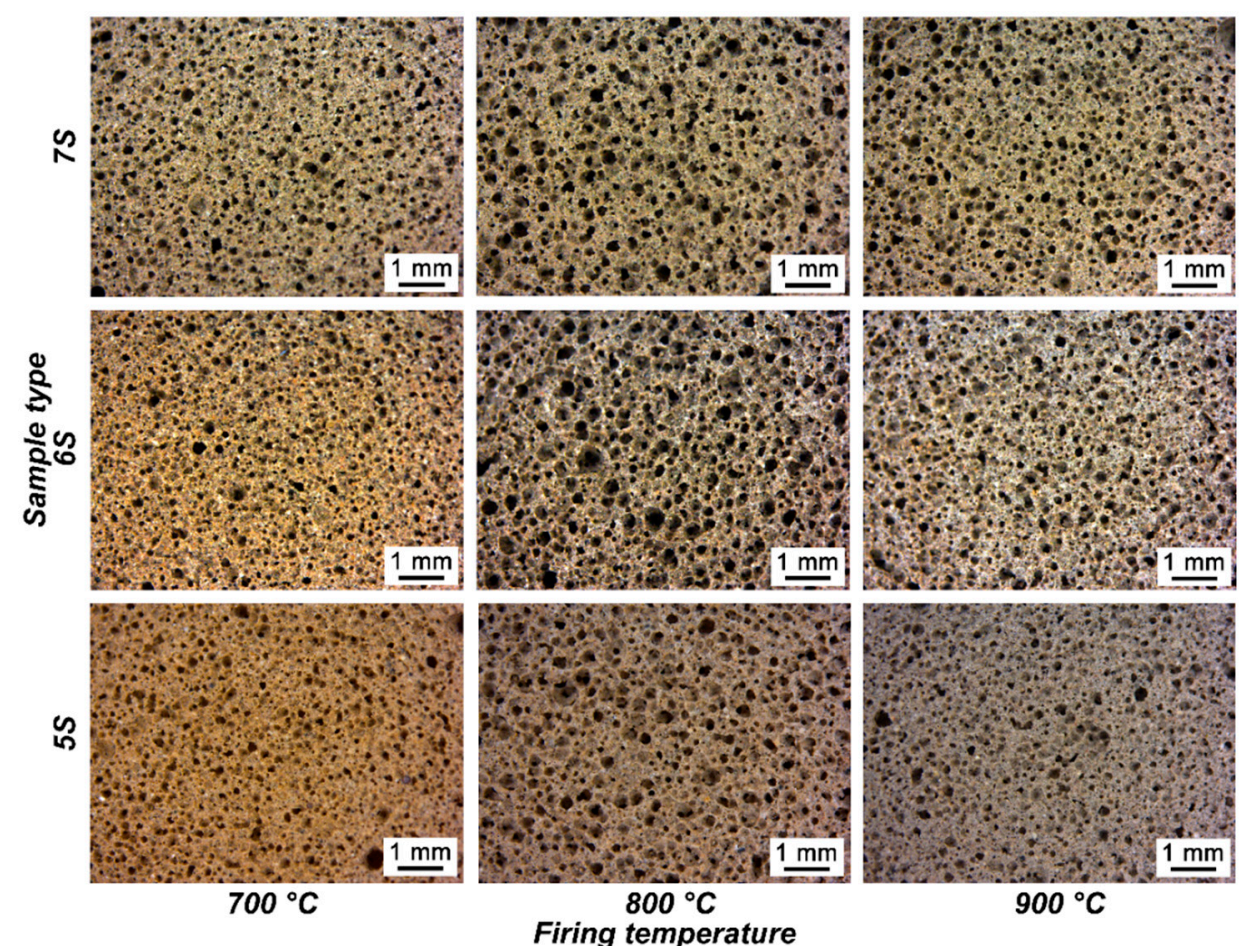

$800^{\circ} \mathrm{C}$

Firing temperature

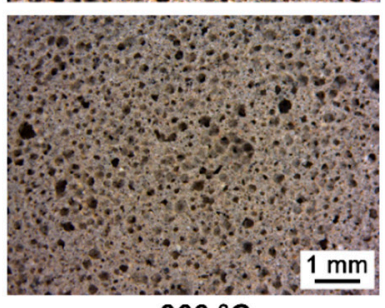

$900{ }^{\circ} \mathrm{C}$

Figure 7. Morphological characterization of the fired foams with different $\mathrm{SiO}_{2} / \mathrm{Al}_{2} \mathrm{O}_{3}$ molar ratio, after firing. 
The evolution of the crystalline phases upon firing is illustrated by the $\mathrm{X}$-ray diffraction patterns in Figure 8. The samples treated at $700{ }^{\circ} \mathrm{C}$ (Figure 8a) show that quartz $\left(\mathrm{SiO}_{2} ; \mathrm{PDF} \# 083-0539\right)$ and mullite $\left(\mathrm{Al}_{4} \mathrm{SiO}_{8} ; \mathrm{PDF} \# 079-1275\right)$ remained as the only identifiable phases. At this temperature, just above the softening point, SLG could just 'glue' FA particles, with limited chemical interaction. By contrast, softened SLG dissolved some quartz, especially for low FA/glass ratio (sample 7S), starting from $800{ }^{\circ} \mathrm{C}$ (Figure 8b). At $800{ }^{\circ} \mathrm{C}$ and, above all, at $900{ }^{\circ} \mathrm{C}$, the SLG/FA interaction was substantial enough to lead to the precipitation of nepheline $\left(\mathrm{Na}_{6.65} \mathrm{Al}_{6.24} \mathrm{Si}_{9.76} \mathrm{O}_{32}, \mathrm{PDF} 083-2372\right)$, a quite typical crystalline phase formed upon transformation of geopolymers at high temperature [39-41].
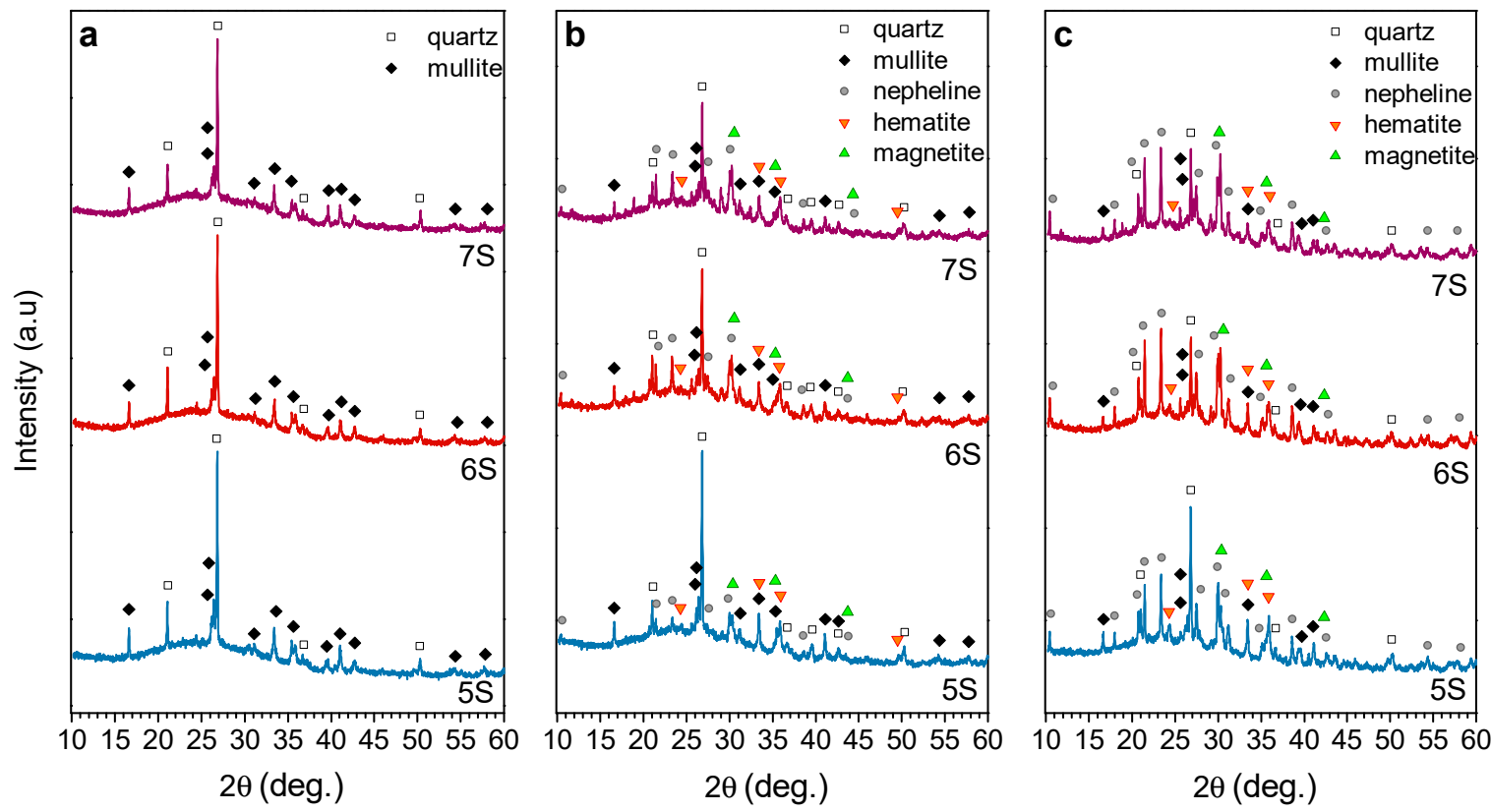

Figure 8. X-ray diffraction patterns of the fired foams with different compositions; (a) $700{ }^{\circ} \mathrm{C}$; (b) $800{ }^{\circ} \mathrm{C}$; and (c) $900{ }^{\circ} \mathrm{C}$.

The increase of temperature also determines the precipitation of iron oxides, in the form of hematite $\left(\mathrm{Fe}_{2} \mathrm{O}_{3}, \mathrm{PDF} \# 89-0691\right)$ and magnetite $\left(\mathrm{Fe}_{3} \mathrm{O}_{4}, \mathrm{PDF} \# 89-0691\right)$. Its relative abundance is difficult to quantify. However, a significant increase of the magnetite can be noticed after the heat treatment at $900{ }^{\circ} \mathrm{C}$.

Density and porosity data of fired samples are shown in Table 2. High total porosity values are achieved, and it may be noted that the porosity remained mostly open for samples of the $5 \mathrm{~S}$ and $6 \mathrm{~S}$ series. Samples with higher glass content (7S) exhibited a more substantial reduction of both overall porosity and open porosity by increasing firing temperature, as an effect of viscous flow. The viscous flow is evident from the microstructural details in Figure 9: Especially samples with relatively low glass content (5S and 6S) were evidently poorly sintered at $700{ }^{\circ} \mathrm{C}$; passing to 800 and $900{ }^{\circ} \mathrm{C}$ effectively led to the mixing of the constituents and to the formation of a uniform solid phase.

The densification with increasing glass content is even more evident considering the morphology of cell struts, shown in Figure 10, for samples fired at $800{ }^{\circ} \mathrm{C}$. It can be appreciated that in the sample with lower glass amount, 5S (Figure 10a), some spherical particles, recognized as fly ash, remained visible; by contrast, they were completely incorporated with higher glass content, with evidence of formation of fibrous crystals. 
Table 2. Density, porosity, and mechanical properties of the fired treated foams at different heating temperatures.

\begin{tabular}{|c|c|c|c|c|c|c|c|c|}
\hline \multirow{2}{*}{ Sample } & \multirow{2}{*}{$\begin{array}{l}\text { Firing } \\
\mathrm{T}^{\mathrm{a}}\left({ }^{\circ} \mathrm{C}\right)\end{array}$} & \multicolumn{3}{|c|}{ Density, $\rho\left(\mathrm{g} / \mathrm{cm}^{3}\right)$} & \multicolumn{3}{|c|}{ Porosity (\%) } & \multirow{2}{*}{$\begin{array}{l}\sigma_{\text {comp }} \\
(\mathrm{MPa})\end{array}$} \\
\hline & & Geometric & Apparent & True & Total & Open & Closed & \\
\hline \multirow{3}{*}{5} & 700 & $0.71 \pm 0.01$ & $2.28 \pm 0.03$ & $2.46 \pm 0.01$ & $71 \pm 1$ & $68 \pm 2$ & $2 \pm 1$ & $1.8 \pm 0.2$ \\
\hline & 800 & $0.82 \pm 0.01$ & $2.32 \pm 0.01$ & $2.49 \pm 0.01$ & $67 \pm 1$ & $64 \pm 1$ & $2 \pm 1$ & $5.1 \pm 0.3$ \\
\hline & 900 & $0.87 \pm 0.01$ & $2.36 \pm 0.01$ & $2.51 \pm 0.01$ & $65 \pm 1$ & $62 \pm 1$ & $2 \pm 1$ & $7.4 \pm 0.3$ \\
\hline \multirow{3}{*}{6} & 700 & $0.54 \pm 0.08$ & $2.25 \pm 0.02$ & $2.42 \pm 0.01$ & $78 \pm 2$ & $75 \pm 3$ & $2 \pm 1$ & $1.9 \pm 0.2$ \\
\hline & 800 & $0.66 \pm 0.01$ & $2.26 \pm 0.02$ & $2.43 \pm 0.01$ & $72 \pm 1$ & $70 \pm 2$ & $2 \pm 1$ & $4.5 \pm 0.2$ \\
\hline & 900 & $0.71 \pm 0.01$ & $2.26 \pm 0.01$ & $2.45 \pm 0.01$ & $70 \pm 3$ & $68 \pm 3$ & $2 \pm 1$ & $5.4 \pm 0.4$ \\
\hline \multirow{3}{*}{7} & 700 & $0.71 \pm 0.01$ & $2.31 \pm 0.06$ & $2.46 \pm 0.01$ & $71 \pm 1$ & $69 \pm 2$ & $2 \pm 1$ & $3.8 \pm 0.2$ \\
\hline & 800 & $0.83 \pm 0.01$ & $2.13 \pm 0.05$ & $2.49 \pm 0.01$ & $66 \pm 2$ & $61 \pm 2$ & $6 \pm 1$ & $5.3 \pm 0.4$ \\
\hline & 900 & $1.02 \pm 0.3$ & $2.08 \pm 0.02$ & $2.44 \pm 0.01$ & $58 \pm 3$ & $50 \pm 4$ & $7 \pm 2$ & $8.7 \pm 0.6$ \\
\hline
\end{tabular}

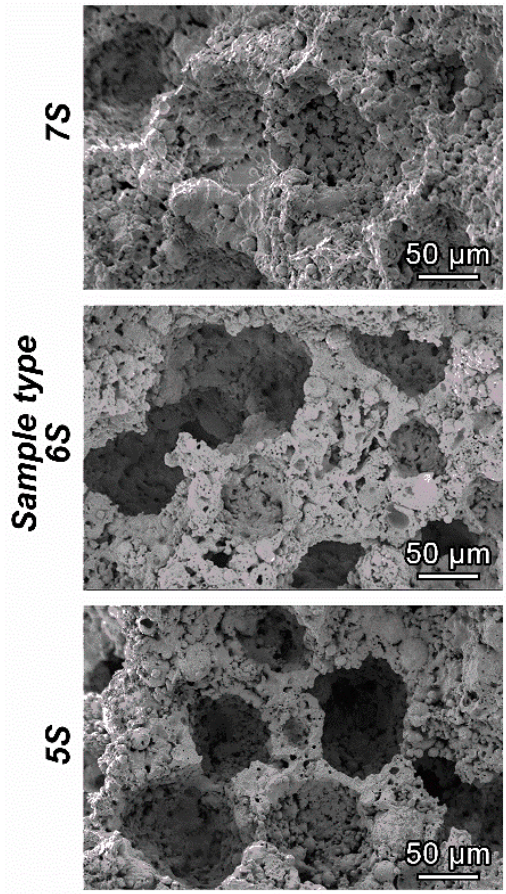

$700^{\circ} \mathrm{C}$
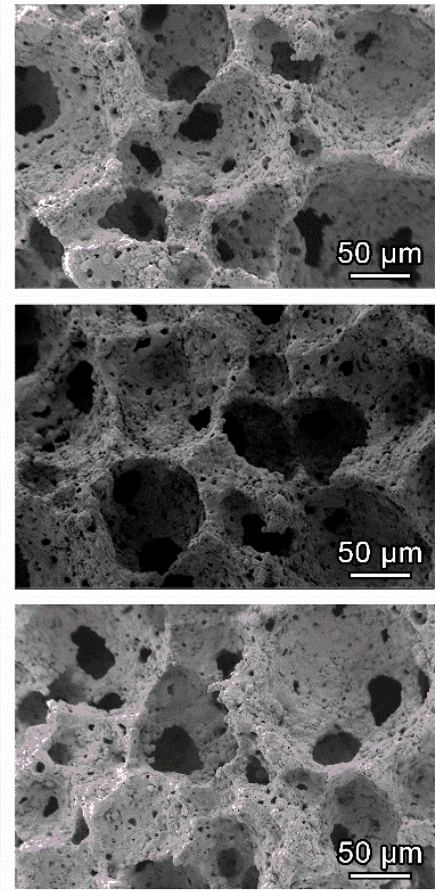

$800^{\circ} \mathrm{C}$

Firing temperature
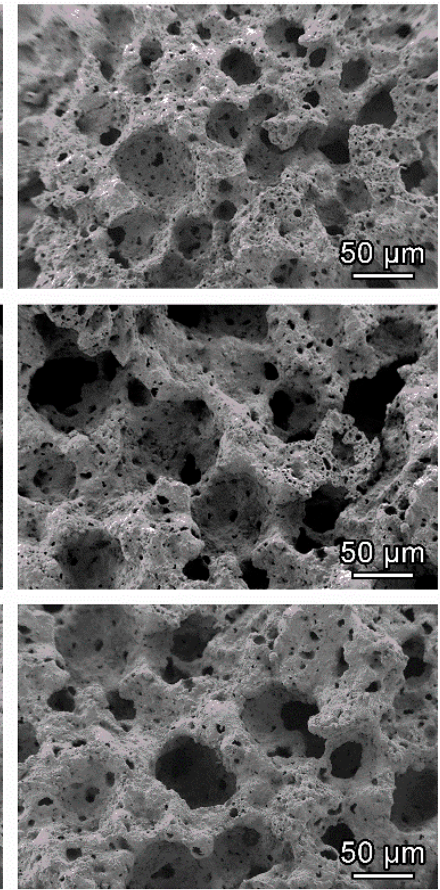

$900^{\circ} \mathrm{C}$

Figure 9. Microstructural details of glass-ceramic foams with different $\mathrm{SiO}_{2} / \mathrm{Al}_{2} \mathrm{O}_{3}$ molar ratio, after firing.
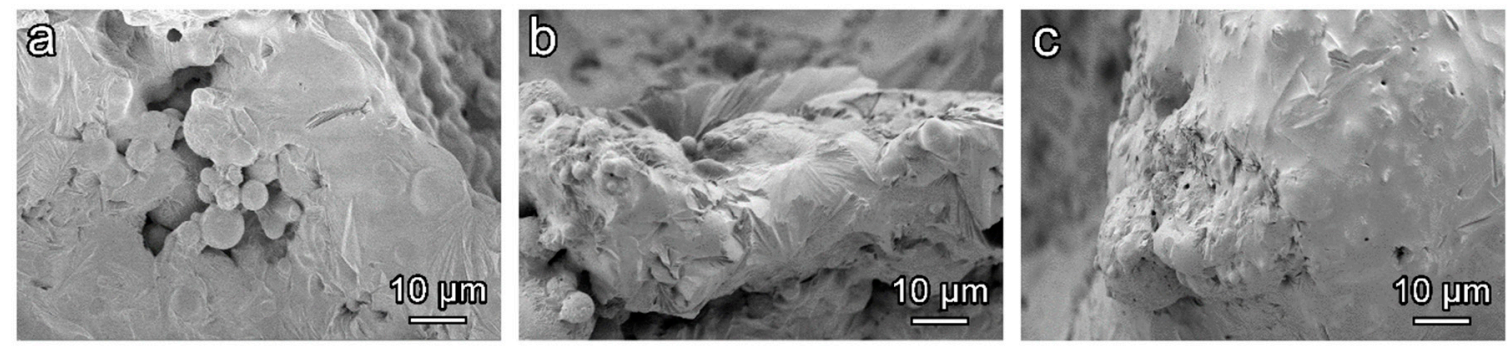

Figure 10. High magnification details of the foams struts after firing at $800{ }^{\circ} \mathrm{C}$; (a) 5S, (b) $6 \mathrm{~S}$, and (c) $7 \mathrm{~S}$. 
The strength data reported in Table 2 are interesting, above all, for the correlation with density data. In fact, any serious comparison should take into account the downscaling of mechanical properties operated by porosity. For samples possessing an abundant overall porosity, with very limited closed porosity (samples of the $5 \mathrm{~S}$ and $6 \mathrm{~S}$ series, $7 \mathrm{~S}$ only fired at $900{ }^{\circ} \mathrm{C}$ ), we may consider a simplified expression of the model proposed by Gibson and Ahsby [42], for the crushing strength $\left(\sigma_{\mathrm{c}}\right)$ of bending-dominated cellular structures, as follows:

$$
\sigma_{\mathrm{c}} \approx \sigma_{\text {bend }} \cdot C \cdot\left(\rho_{\text {rel }}\right)^{3 / 2}
$$

where the relative density $\left(\rho_{\text {rel }}\right)$ is defined as $\rho_{\text {rel }}=1-\mathrm{P} / 100$ ( $\mathrm{P}$ is the total porosity), $\mathrm{C}$ is a dimensionless constant $(\sim 0.2)$, and $\sigma_{\text {bend }}$ is the bending strength of the solid phase. If we consider the relative densities of samples $5 \mathrm{~S}$ and $6 \mathrm{~S}$ fired at $800-900{ }^{\circ} \mathrm{C}$, and of sample $7 \mathrm{~S}$ fired at $700{ }^{\circ} \mathrm{C}$, ranging from 0.3 to 0.35 , the observed crushing strength values (marked in bold character in Table 2) are remarkable. In fact, these values correspond to a bending strength of the solid phase well above $100 \mathrm{MPa}$, in turn exceeding the bending strength of most glasses [43].

Table 3 shows the chemical analysis of the leachate of the glass-ceramic foams after the heat treatment at 800 and $900{ }^{\circ} \mathrm{C}$ and the initial raw materials. According to EN-12457, the leachates of the selected samples are well below the thresholds for inert materials in all the analyzed metal ions, with just one exception. The $5 \mathrm{~S}$ sample treated at $800{ }^{\circ} \mathrm{C}$ exhibited a release of molybdenum ions slightly above the limit, but it should be considered as safe in any case, observing that the leaching tests were applied on highly porous samples, featuring a high surface-to-volume ratio, i.e., in particularly severe conditions.

Table 3. Leachate chemical analysis of selected samples and initial materials.

\begin{tabular}{|c|c|c|c|c|c|c|c|c|c|c|}
\hline \multirow[t]{2}{*}{$\begin{array}{c}\text { Element } \\
\text { (ppm) }\end{array}$} & \multicolumn{2}{|c|}{$5 \mathrm{~S} 3 \mathrm{M}$} & \multicolumn{2}{|c|}{$6 \mathrm{~S} 3 \mathrm{M}$} & \multicolumn{2}{|c|}{$7 \mathrm{~S} 3 \mathrm{M}$} & \multicolumn{2}{|c|}{ Initial Materials } & \multicolumn{2}{|c|}{ Limits [UE] (ppm) } \\
\hline & 800 & 900 & 800 & 900 & 800 & 900 & FA & SLG & $\begin{array}{c}\text { Inert } \\
\text { material }\end{array}$ & $\begin{array}{c}\text { Non- } \\
\text { hazardous } \\
\text { material }\end{array}$ \\
\hline As & 0.0316 & 0.0635 & 0.068 & 0.0503 & 0.0491 & 0.0795 & $<0.0049$ & $<0.0049$ & 0.5 & 2 \\
\hline $\mathrm{Ba}$ & $>\mathrm{al}$ & $>\mathrm{al}$ & $>\mathrm{al}$ & $>\mathrm{al}$ & 0.0672 & 0.1108 & $<0.000$ & $>\mathrm{al}$ & 20 & 100 \\
\hline $\mathrm{Cd}$ & $<0.0002$ & $<0.0002$ & $<0.0002$ & $<0.0002$ & $<0.0002$ & $<0.0002$ & $<0.0002$ & 0.001 & 0.04 & 1 \\
\hline $\mathrm{Cr}$ & 0.3406 & 0.0805 & 0.0255 & 0.0598 & 0.0689 & 0.3001 & 0.4672 & 0.0043 & 0.5 & 10 \\
\hline $\mathrm{Cu}$ & 0.0029 & 0.0183 & 0.0024 & 0.0065 & 0.0053 & 0.0207 & 0.0282 & 0.0036 & 2 & 50 \\
\hline $\mathrm{Hg}$ & 0.0032 & $<0.0004$ & 0.0006 & $<0.0004$ & 0.0020 & 0.0017 & 0.8983 & $<0.0004$ & 0.01 & 0.2 \\
\hline Mo & 0.5324 & 0.0472 & 0.2107 & 0.0087 & 0.1973 & 0.2435 & $<0.0004$ & 0.007 & 0.5 & 10 \\
\hline $\mathrm{Ni}$ & $<0.0014$ & $<0.0014$ & $<0.0014$ & $<0.0014$ & $<0.0014$ & $<0.0014$ & $<0.0014$ & $<0.0014$ & 0.4 & 10 \\
\hline $\mathrm{Pb}$ & $<0.0047$ & $<0.0047$ & $<0.0047$ & $<0.0047$ & $<0.0047$ & $<0.0047$ & $<0.0047$ & 0.018 & 0.5 & 10 \\
\hline $\mathrm{Se}$ & 0.0133 & $<0.0122$ & 0.0255 & $<0.0122$ & 0.0226 & $<0.0122$ & $<0.0122$ & 0.018 & 0.1 & 0.5 \\
\hline Zn & $<0.0203$ & $<0.0203$ & $<0.0203$ & $<0.0203$ & $<0.0203$ & $<0.0203$ & $<0.0203$ & 0.088 & 4 & 50 \\
\hline $\mathrm{pH}$ & 9.4 & 8.6 & 8.2 & 7.7 & 8.0 & 7.6 & & & & \\
\hline
\end{tabular}

The stabilization of the potential pollutants present in the initial waste materials supports the possible use of the waste-derived glass-ceramic foams as environmentally friendly materials for thermal and acoustic insulation. For this reason, selected samples were produced on a semi-industrial scale, given that the proposed method with alkali activation and foaming is beneficial in the manufacturing of large panels. In addition, low-temperature foaming does not imply any geometrical limitation. The firing temperature $\left(800^{\circ} \mathrm{C}\right)$ is far below that adopted in the case of cheapest ceramics for building applications, such as clay bricks.

The overall aspect of the $5 \mathrm{~S}$ hardened lightweight panels produced with a big mold, after $24 \mathrm{~h}$ of post-foaming, is illustrated in Figure 11a (thickness of about $20 \mathrm{~mm}$ ). The panels show good consistency with no cracks and acceptable mechanical properties, which make them easy to handle. After firing at $800{ }^{\circ} \mathrm{C}$ (Figure $11 \mathrm{~b}$ ), the overall structure remained unaltered, as observed on laboratory scale 
(the sample shown here was not cut or rectified). The faster heat treatment applied in a semi-industrial furnace did not cause the formation of any visible cracks (no preheating was applied to the samples, since they were inserted directly into the furnace).
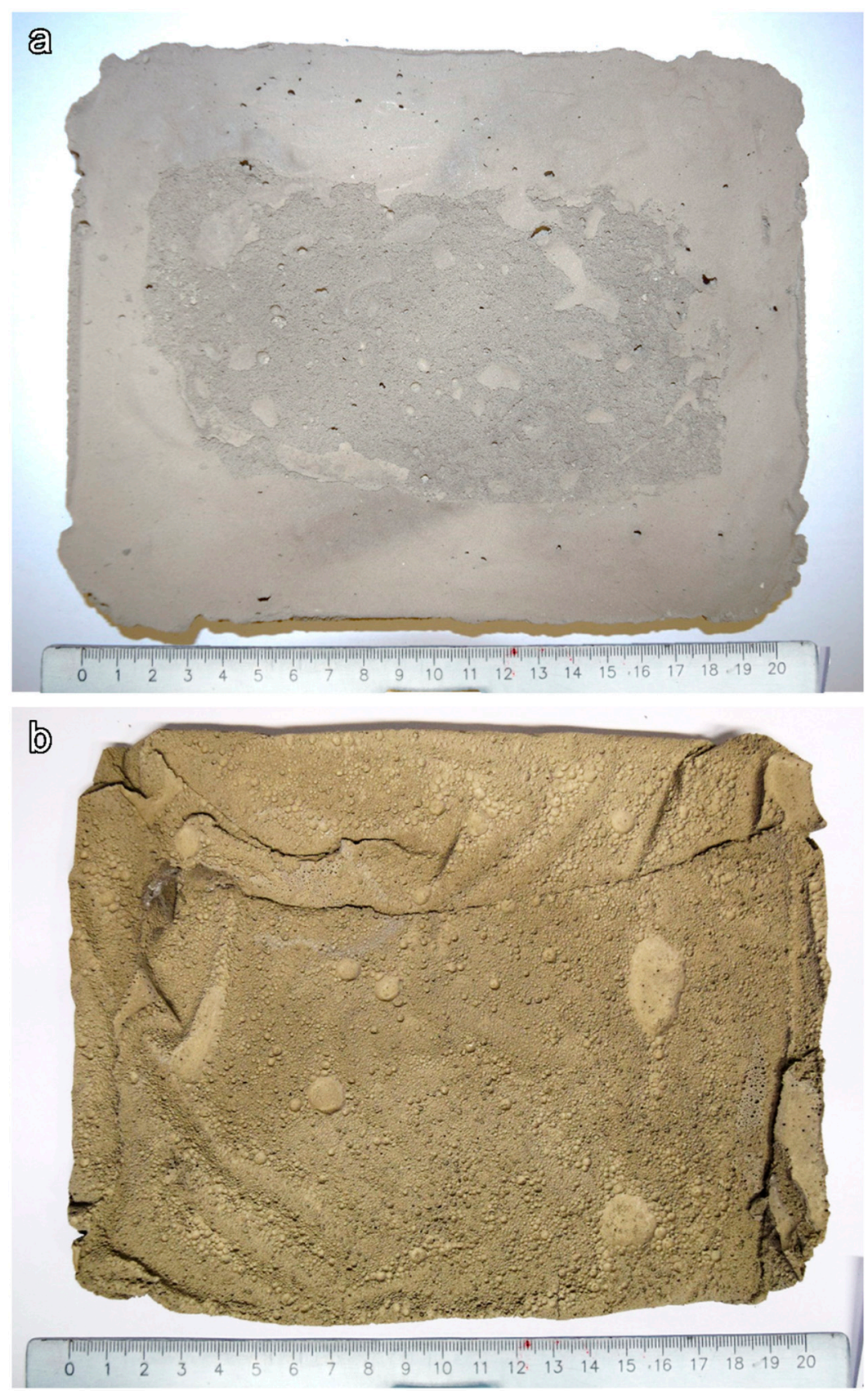

Figure 11. General view of lightweight panels; (a) $6 \mathrm{~S}$ hardened panel; (b) heat treated panel at $800{ }^{\circ} \mathrm{C}$.

The thermal conductivity measured at $25{ }^{\circ} \mathrm{C}$ in the $5 \mathrm{~S}$ samples treated at $800{ }^{\circ} \mathrm{C}$ was $0.163 \pm 0.005 \mathrm{~W} \cdot \mathrm{m}^{-1} \cdot \mathrm{K}^{-1}$. Such a relatively low value could be explained due to the low density and the particular cellular structure developed in the panels. Despite the open porosity, the reduced size and the homogeneous distribution probably had an advantageous effect, by reducing air convection [44]. These optimized foam panels could find applications in the building industry, as thermal insulators; moreover, the open-celled morphology presented by the ceramic foams along with the abundant content of iron oxide could support additional applications, e.g., as catalytic supports. 


\section{Conclusions}

We may conclude that:

- The technique ensures an excellent approach to produce glass-ceramic foams allowing the incorporation of high proportions of fly ash.

- This approach provides a recycling route to glass fraction currently landfilled, providing a solution to the landfill derived problems as well as a significant economic advantage.

- The possibility to use low alkali activator concentrations to produce a geopolymer-like gel, which acts as a binding phase, is demonstrated.

- The decomposition of the gel and the SLG/FA interactions upon firing promote the formation of the glass-ceramic foams.

- The developed glass-ceramic foams have high porosity, low thermal conductivity, and reasonable mechanical properties to be applied as thermal insulation materials.

- The chemical stability of the glass ceramic foams was assessed by leaching tests; the release of heavy metals remained below the threshold specification for inert materials.

Author Contributions: For this paper, E.B. and A.R.B. formulated research ideas and supervised the experiments. A.R.R. and N.T. performed the general experimentation. A.R.R. and E.B. have written and edited the article. All authors read, corrected, and approved the article.

Funding: The authors acknowledge the support of the European Community's Horizon 2020 Programme through a Marie Skłodowska-Curie Innovative Training Network ('CoACH-ETN”, g.a. no. 642557).

Acknowledgments: The authors thank SASIL S.p.a. (Brusnengo, Biella, Italy), for the supply of the soda-lime glass and experiments on bigger samples, and Steag Power Minerals (Gladbeck, Germany), for the supply of the fly ash. The authors also thank Matteo Cavasin Element (Hitchin, United Kingdom) for the support with the thermal conductivity measurements.

Conflicts of Interest: The authors declare no conflict of interest.

\section{References}

1. Blissett, R.S.; Rowson, N.A. A review of the multi-component utilisation of coal fly ash. Fuel 2012, 97, 1-23. [CrossRef]

2. Carlson, C.L.; Adriano, D.C. Environmental impacts of coal combustion residues. J. Environ. Qual. 1993, 22, 227-247. [CrossRef]

3. Fernandes, H.R.; Tulyaganov, D.U.; Ferreira, J.M.F. Preparation and characterization of foams from sheet glass and fly ash using carbonates as foaming agents. Ceram. Int. 2009, 35, 229-235. [CrossRef]

4. Asokan, P.; Saxena, M.; Asolekar, S.R. Coal combustion residues-Environmental implications and recycling potentials. Resour. Conserv. Recycl. 2005, 43, 239-262. [CrossRef]

5. Kulasuriya, C.; Vimonsatit, V.; Dias, W.; De Silva, P. Design and development of Alkali Pozzolan Cement (APC). Constr. Build. Mater. 2014, 68, 426-433. [CrossRef]

6. Bui, P.T.; Ogawa, Y.; Nakarai, K.; Kawai, K. Effect of internal alkali activation on pozzolanic reaction of low-calcium fly ash cement paste. Mater. Struct. Mater. Constr. 2016, 49, 3039-3053. [CrossRef]

7. Leroy, C.; Ferro, M.C.; Monteiro, R.C.C.; Fernandes, M.H.V. Production of glass-ceramics from coal ashes. J. Eur. Ceram. Soc. 2001, 21, 195-202. [CrossRef]

8. Barbieri, L.; Lancellotti, I.; Manfredini, T.; Ignasi, Q.; Rincon, J.; Romero, M. Design, obtainment and properties of glasses and glass-ceramics from coal fly ash. Fuel 1999, 78, 271-276. [CrossRef]

9. Wu, J.P.; Boccaccini, A.R.; Lee, P.D.; Kershaw, M.J.; Rawlings, R.D. Glass ceramic foams from coal ash and waste glass: Production and characterisation. Adv. Appl. Ceram. 2006, 105, 32-39. [CrossRef]

10. Bai, J.; Yang, X.; Xu, S.; Jing, W.; Yang, J. Preparation of foam glass from waste glass and fly ash. Mater. Lett. 2014, 136, 52-54. [CrossRef]

11. Mi, H.; Yang, J.; Su, Z.; Wang, T.; Li, Z.; Huo, W.; Qu, Y. Preparation of ultra-light ceramic foams from waste glass and fly ash. Adv. Appl. Ceram. 2017, 116, 400-408. [CrossRef]

12. Wei, Y.-L.; Cheng, S.-H.; Ko, G.-W. Effect of waste glass addition on lightweight aggregates prepared from F-class coal fly ash. Constr. Build. Mater. 2016, 112, 773-782. [CrossRef] 
13. Feng, J.; Zhang, R.; Gong, L.; Li, Y.; Cao, W.; Cheng, X. Development of porous fly ash-based geopolymer with low thermal conductivity. Mater. Des. 2015, 65, 529-533. [CrossRef]

14. Xu, H.; Van Deventer, J.S.J. The geopolymerisation of alumino-silicate minerals. Int. J. Miner. Process. 2000, 59, 247-266. [CrossRef]

15. Palomo, A.; Grutzeck, M.W.; Blanco, M.T. Alkali-activated fly ashes: A cement for the future. Cem. Concr. Res. 1999, 29, 1323-1329. [CrossRef]

16. Toniolo, N.; Boccaccini, A.R. Fly ash-based geopolymers containing added silicate waste. A review. Ceram. Int. 2017, 43, 14545-14551. [CrossRef]

17. Swanepoel, J.C.; Strydom, C.A. Utilisation of fly ash in a geopolymeric material. Appl. Geochem. 2002, 17, 1143-1148. [CrossRef]

18. Fernández-Jiménez, A.; Palomo, A.; Criado, M. Microstructure development of alkali-activated fly ash cement: A descriptive model. Cem. Concr. Res. 2005, 35, 1204-1209. [CrossRef]

19. McLellan, B.C.; Williams, R.P.; Lay, J.; van Riessen, A.; Corder, G.D. Costs and carbon emissions for geopolymer pastes in comparison to ordinary portland cement. J. Clean. Prod. 2011, 19, 1080-1090. [CrossRef]

20. Komljenović, M.; Baščarević, Z.; Bradić, V. Mechanical and microstructural properties of alkali-activated fly ash geopolymers. J. Hazard. Mater. 2010, 181, 35-42. [CrossRef]

21. Somna, K.; Jaturapitakkul, C.; Kajitvichyanukul, P.; Chindaprasirt, P. NaOH-activated ground fly ash geopolymer cured at ambient temperature. Fuel 2011, 90, 2118-2124. [CrossRef]

22. Puertas, F.; Torres-Carrasco, M. Use of glass waste as an activator in the preparation of alkali-activated slag. Mechanical strength and paste characterisation. Cem. Concr. Res. 2014, 57, 95-104. [CrossRef]

23. Fernández-Jiménez, A.; Cristelo, N.; Miranda, T.; Palomo, Á. Sustainable alkali activated materials: Precursor and activator derived from industrial wastes. J. Clean. Prod. 2017, 162, 1200-1209. [CrossRef]

24. Zhang, S.; Keulen, A.; Arbi, K.; Ye, G. Waste glass as partial mineral precursor in alkali-activated slag/fly ash system. Cem. Concr. Res. 2017, 102, 29-40. [CrossRef]

25. Toniolo, N.; Rincón, A.; Roether, J.A.; Ercole, P.; Bernardo, E.; Boccaccini, A.R. Extensive reuse of soda-lime waste glass in fly ash-based geopolymers. Constr. Build. Mater. 2018, 188, 1077-1084. [CrossRef]

26. Toniolo, N.; Rincón, A.; Avadhut, Y.S.; Hartmann, M.; Bernardo, E.; Boccaccini, A.R. Novel geopolymers incorporating red mud and waste glass cullet. Mater. Lett. 2018, 219, 152-154. [CrossRef]

27. Standard Specification for Coal Fly Ash and Raw or Calcined Natural Pozzolan for Use in Concrete; ASTM Committee C-09 on Concrete and Concrete Aggregates: West Conshohocken, PA, USA, 2013.

28. Ranjbar, N.; Mehrali, M.; Alengaram, U.J.; Metselaar, H.S.C.; Jumaat, M.Z. Compressive strength and microstructural analysis of fly ash/palm oil fuel ash based geopolymer mortar under elevated temperatures. Constr. Build. Mater. 2014, 65, 114-121. [CrossRef]

29. Studart, A.R.; Gonzenbach, U.T.; Tervoort, E.; Gauckler, L.J. Processing Routes to Macroporous Ceramics: A Review. J. Am. Ceram. Soc. 2006, 89, 1771-1789. [CrossRef]

30. Álvarez-Ayuso, E.; Querol, X.; Plana, F.; Alastuey, A.; Moreno, N.; Izquierdo, M.; Font, O.; Moreno, T.; Diez, S.; Vázquez, E.; et al. Environmental, physical and structural characterisation of geopolymer matrixes synthesised from coal (co-)combustion fly ashes. J. Hazard. Mater. 2008, 154, 175-183. [CrossRef]

31. Torres-Carrasco, M.; Puertas, F. Waste glass in the geopolymer preparation. Mechanical and microstructural characterisation. J. Clean. Prod. 2015, 90,397-408. [CrossRef]

32. Rattanasak, U.; Chindaprasirt, P. Influence of $\mathrm{NaOH}$ solution on the synthesis of fly ash geopolymer. Miner. Eng. 2009, 22, 1073-1078. [CrossRef]

33. Desbats-Le Chequer, C.; Frizon, F. Impact of sulfate and nitrate incorporation on potassium- and sodium-based geopolymers: Geopolymerization and materials properties. J. Mater. Sci. 2011, 46, 5657-5664. [CrossRef]

34. Hu, N.; Bernsmeier, D.; Grathoff, G.H.; Warr, L.N. The influence of alkali activator type, curing temperature and gibbsite on the geopolymerization of an interstratified illite-smectite rich clay from Friedland. Appl. Clay Sci. 2017, 135, 386-393. [CrossRef]

35. Fernández-Jiménez, A.; Palomo, A. Composition and microstructure of alkali activated fly ash binder: Effect of the activator. Cem. Concr. Res. 2005, 35, 1984-1992. [CrossRef]

36. Katz, A. Microscopic Study of Alkali-Activated Fly Ash. Cem. Concr. Res. 1998, 28, 197-208. [CrossRef] 
37. Li, J.; Zhuang, X.; Monfort, E.; Querol, X.; Llaudis, A.S.; Font, O.; Moreno, N.; Ten, F.J.G.; Izquierdo, M. Utilization of coal fly ash from a Chinese power plant for manufacturing highly insulating foam glass: Implications of physical, mechanical properties and environmental features. Constr. Build. Mater. 2018, 175, 64-76. [CrossRef]

38. ul Haq, E.; Kunjalukkal Padmanabhan, S.; Licciulli, A. Synthesis and characteristics of fly ash and bottom ash based geopolymers-A comparative study. Ceram. Int. 2014, 40, 2965-2971. [CrossRef]

39. Bakharev, T. Thermal behaviour of geopolymers prepared using class $\mathrm{F}$ fly ash and elevated temperature curing. Cem. Concr. Res. 2006, 36, 1134-1147. [CrossRef]

40. Dombrowski, K.; Buchwald, A.; Weil, M. The influence of calcium content on the structure and thermal performance of fly ash based geopolymers. J. Mater. Sci. 2007, 42, 3033-3043. [CrossRef]

41. Kuenzel, C.; Grover, L.M.; Vandeperre, L.; Boccaccini, A.R.; Cheeseman, C.R. Production of nepheline/quartz ceramics from geopolymer mortars. J. Eur. Ceram. Soc. 2013, 33, 251-258. [CrossRef]

42. Gibson, L.J.; Ashby, M.F. Cellular Solids: Structure and Properties, 2nd ed.; Cambridge University Press: Cambridge, UK, 2014; pp. 1-510.

43. Bernardo, E.; Scarinci, G.; Maddalena, A.; Hreglich, S. Development and mechanical properties of metal-particulate glass matrix composites from recycled glasses. Compos. Part A Appl. Sci. Manuf. 2004, 35, 17-22. [CrossRef]

44. Petersen, R.R.; König, J.; Yue, Y. The mechanism of foaming and thermal conductivity of glasses foamed with $\mathrm{MnO}_{2}$. J. Non-Cryst. Solids 2015, 425, 74-82. [CrossRef]

(C) 2019 by the authors. Licensee MDPI, Basel, Switzerland. This article is an open access article distributed under the terms and conditions of the Creative Commons Attribution (CC BY) license (http:/ / creativecommons.org/licenses/by/4.0/). 